\title{
Results Obtained from Maize Production During the Period 2012-2013 in Minimum Tillage, at Ards Turda
}

\author{
Felicia CHEȚAN $^{1,2}$, Teodor RUSU ${ }^{2}$, Cornel CHEȚAN ${ }^{1,2}$, Alina ŞIMON ${ }^{1,2}$, Mircea IGNEA $^{1}$ \\ ${ }^{1}$ Agricultural Research and Development Station, Turda, 27 Agriculturii Street, Cluj County, Romania, \\ Email:felice_fely@yahoo.com \\ ${ }^{2}$ University of Agricultural Sciences and Veterinary Medicine Cluj-Napoca, 3-5, Manastur Street, \\ 400372, Romania, Email: trusu@usamvcluj.ro
}

Bulletin USAMV serie Agriculture 71(1-2)/2014

Print ISSN 1843-5246; Electronic ISSN 1843-5386

DOI: 10.15835/buasvm-agr: 10256

\begin{abstract}
Minimum tillage systems on soil chasing the conservation and efficient use of natural resources, biological and water. By surrendering to plowghing with moldboard plow in whole or in part by streamlining periodic tillage and keep at the ground surface of at least $15-30 \%$ of all plant debris, protect soil the sheeterosion, it also eliminating at the same time the phenomenon of soil compaction. A proper crop rotation is alternating in culture plants with strong rooting with shallow rooting plants, leguminous plants have favorable effect for the successor cultures, soil nitrogen impruvement and contributing to the development of the root system. In research conducted at ARDS Turda on 2012-2013, in the cultivation of maize in the system with minimal compared to classic productions obtained system reflects the fact that maize is still a pretentious plant both climatic conditions and approach towards soil requirements. The influence of the year are very strong for corn production, he differences being of $689 \mathrm{~kg} / \mathrm{ha}$ in the variant with a seeding and fertilization along with $414 \mathrm{~kg} / \mathrm{ha}$ in the variant with additional fertilization. By applying minimum tillage system soil aims primarily to combat soil erosion and water retention in the soil so it is so specially important to watch the long term effect of applying them to the environment.
\end{abstract}

Keywords: maize, minimum tillage system, climatic condition, yield

\section{INTRODUCTION}

World demand and grain growing, being subject to overload earth it will exhaust resources, accelerating the process of erosion with serious long-term consequences (Brown, 1984). Agricultural technology used by mechanization, chimization, the man and the master component aware of the biological processes taking place in the agroesosystems can uses rational these ecological conditions, the development of large production and at the same time ensuring a constant proper preservation of all habitats.

Maintaining a certain ballances in agroecosystem is the foundation of sustainable agriculture through agrotechnics measures and the works required, ensure the adjustment its components, without irreversible ecological consequences (Rusu et al., 2005). The ecological framework on
Transylvania is the existence of the interaction of a large number of factors, two of which manifest a dominant action for agroecosystem; the first is to fund the level or low temperature, and with large temporal variation, the features wich require significant restriction for thermophilic plants such as: maize, sun- flower, soybean, sorghum a.s and the second is hilly orographics. The interaction of environmental factors in relation to antropogenic land condition influenced with many soil degraded by erosion or temporaly excess of moisture (Rusu et Gus, 2007; Gus et Rusu, 2011) which impose restrictions on the structure of the system, machine and tractor station to ensure the mechanization on the slope.

Large corn-growing countries in Europe in 2012 were: Romania with an area of, 2,722,180 hectares (but second place as total yields obtai- 


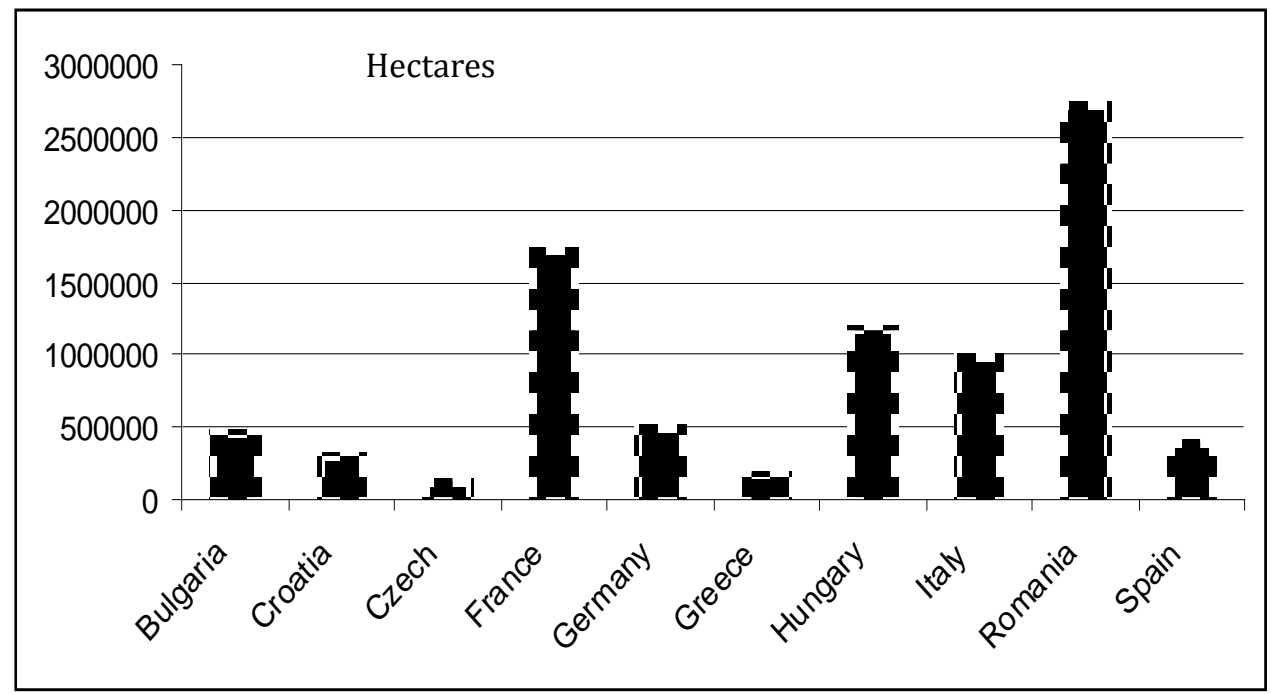

Fig. 1. The largest surfaces cultivated with maize in Europe, 2012

ned), France from, 1,718,600 hectares (first as total production) and Hungary with 1,190,000 hectares (fig. 1, INS, 2013). The total area of land cultivated with corn from EU States was 9,789,512 hectares and World USA is in first place with a surface of 35,259,790 hectares of maize.

Maize is one of the most important culture crops worldwide, its use is: people food, feedstuff industry in the manufacture of bioethanol (Scurtu, 2001). Corn has high demands of climatic factors and approach towards edaphic, temperature being the limiting factor in the area of culture's expansion throughout the duration of vegetation and requiring monthly average temperatures: $20^{\circ} \mathrm{C}$ in 16 may, $19-20^{\circ} \mathrm{C}$ in June, than $21^{\circ} \mathrm{C}-23^{\circ} \mathrm{C}$ in July, $19-22^{\circ} \mathrm{C}$ in august and $14-17^{\circ} \mathrm{C}$ in September, in close conection with the production. Approach towards moisture, corn is pretentious but, due to the coefficient reduced sweating (230-440), a well developed root system and opportunities opening not only to reduce the surface of sweating through the leaf in case of twining leaves, is considered a plant resistance to drought (Muntean et al., 2008; Has et al., 2010). Of great importance are high rainfall from October to April, and soil water reserve in the magic corectă to entail the establishment of sowing density (Gus et al., 2004).

Part of the conservative, non-conventional systems agriculture, minimum soil tillage system that represents one of the most important elements of technology. Unconventional system, means giving up plowing with moldboarg plow total or periodically, the rationalization of the number of works and keeping the soil surface of at least $15-30 \%$ of the total vegetable scraps (Rusu, 2005; Marin et al., 2012; Chețan et al., 2013; Simon et al., 2013). By applying this system aims to reduce soil erosion and compactation, soil and water conservation, protection of plants with nonpolluting substances to the environment (Fabrizzi et al., 2005; Moraru et al., 2010; Bucur et al., 2011; Rusu et al., 2014; Ivaș et al., 2013; Malschi et al., 2013).

The conservative soiltillage of the maintenance of the soil must be aimed at in accumulation and keeping of water in the soil. Considering the upcoming plants (Chețan et al., 2013) the degree of weeds, the pedoclimatic factors, these condition are differentiaded executed, with chisel since autumn with incorporation plant debris in the firsts $20 \mathrm{~cm}$ in the soil (Rusu, 2005; Rusu et al., 2005). The climate changes taking place both locally and globally, require the adoption of new agricultural technologies, suitable to the new climatic conditions (Grecu et al., 2011; Rusu et al., 2014).

Purpose of research is the development an the conservativ system through the experimentation in conventional system and minimum tillage in relation with fertilization and combinations of treatments with fertilisers, fungicides and insecticides. 


\section{MATERIALS AND METHODS}

The experiment realised in 2012-2013 at ARDS Turda, situated in Transylvania Plain, on a preluvosol with texture sandy loam-clay type, $\mathrm{pH}$ neutral, supply good and very good with mobile phosphorus (more than $4.5 \% \mathrm{mg} \mathrm{P}_{2} \mathrm{O}_{5} / 100 \mathrm{~g}$ soil) and potassium (more than $30 \mathrm{mg} \mathrm{K} \mathrm{O} / 100$ g soil), soil in humus content is medium $(3.5 \%)$. Characteristically this type of soil is the rapid subsidence, when passing with of heavy aggregates on the surface or where tillage is carried out under conditions of high humidity. The experiment realised is an threefactorial experiment, type AxBxC-R:2x2x4-3. Experimental plots is a surface of $48 \mathrm{~m}^{2}$ (12 $\mathrm{m}$ in lenght $\mathrm{x} 4 \mathrm{~m}$ in width).

The experience is being organized by the method of the plots subdivided. Determination of production was achieved through harvesting (manually), weighing the cobs, separating seeds of cobs (manually), calculated per hectare production, followeed by correcting the STAS humidy of $15.5 \%$. In the experience of maize seeding he was realised with, MT 6-Maschio Gaspardo machine, used Turda Star hybrid (midle early hybrid, the FAO group 300-400, created at ARDS Turda, 2005), seeds treated with insectofungicides against deseases and pest (Royal Flo $42 \mathrm{~S} 3.5 \mathrm{l}$ /ton of seeds). Density of seeding was 65,000 plants/ha and incorporation depth $5 \mathrm{~cm}$.

The experimental factors are: The system of soil work (A): 2 graduation: $A_{1}$ - conventional method with plowghing - preparation of the soil - seeding + fertilizing; $A_{2}$ - minimum tillage: work with chisel. Fertilization (B): 2 graduation: $\mathrm{B}_{1}$ - fertilizing with $\mathrm{N}_{40} \mathrm{P}_{40}$ at the same with seeding; $\mathrm{B}_{2}$ - fertilizing with $\mathrm{N}_{40} \mathrm{P}_{40}$ at the same with seeding + fertilizing with $\mathrm{N}_{40}$ in 4 - 6 leaves of maize. Factor (C) treatments, include combination with foliar fertilizers, fungicides and insecticides. Application of the treatments are done in two important phenological moments during the growing season: I phenophases 3-5 leaves with foliar fertilizers + insecticide. For weed control, herbicide was applied Esteron (0.8 l per ha + Trend 0.3 l per ha); II phenophases 7-9 leaves, foliar fertilizer + insecticide + fungicide (table 1).

The climatic conditions of the experimental period are presented in table 2 and table 3 (Turda Weather Station).

Tab. 1. Application of the maize treatments

\begin{tabular}{ccc}
\hline Variances & Phenophases 3-5 leaves & Phenophases 7-9 leaves \\
\hline $\mathrm{C}_{1}$ & $\mathrm{IF}+\mathrm{IS}$ & $\mathrm{IF}+\mathrm{IS}$ \\
\hline $\mathrm{C}_{2}$ & $\mathrm{IS}$ & $\mathrm{IF}$ \\
\hline $\mathrm{C}_{3}$ & $\mathrm{IS}+\mathrm{IF}$ & $\mathrm{IF}$ \\
\hline $\mathrm{C}_{4}$ & $\mathrm{IF}$ & - \\
\hline
\end{tabular}

Legend: IF - foliar fertilizer, IS - insecticide, FG - fungicide.

Tab. 2. Thermic regime for period 2012-2013, ARDS Turda

\begin{tabular}{|c|c|c|c|c|c|c|c|c|c|c|c|c|}
\hline \multirow{2}{*}{ Years } & \multicolumn{12}{|c|}{ Temperatures registred, ${ }^{\circ} \mathrm{C}$} \\
\hline & I & II & III & IV & $\mathrm{V}$ & $\mathrm{VI}$ & VII & VIII & IX & $\mathrm{X}$ & $\mathrm{XI}$ & XII \\
\hline 2012 & -2.3 & -6.1 & 4.7 & 11.8 & 16.2 & 21.0 & 24.0 & 22.3 & 19.1 & 11.4 & 5.2 & -2.6 \\
\hline 2013 & -2.4 & 2.0 & 3.5 & 12.3 & 16.8 & 19.4 & 20.9 & 22.1 & 13.8 & 11.2 & 7.1 & -1.7 \\
\hline Average from 55 years & -3.5 & -0.9 & 4.1 & 9.8 & 14.7 & 17.7 & 19.6 & 19.2 & 14.9 & 9.6 & 3.7 & -1.5 \\
\hline
\end{tabular}

Tab. 3. Pluviometric regime for period 2012-2013, ARDS Turda

\begin{tabular}{ccccccccccccc}
\hline \multirow{2}{*}{ Years } & \multicolumn{10}{c}{ Precipitation registred, mm } \\
\cline { 2 - 13 } & I & II & III & IV & V & VI & VII & VIII & IX & X & XI & XII \\
\hline 2012 & 26.2 & 30.7 & 5.3 & 78.4 & 89.2 & 67.4 & 52.4 & 28.0 & 30.2 & 42.0 & 9.6 & 45.0 \\
\hline 2013 & 19.8 & 10.3 & 57.9 & 53.3 & 79.3 & 86.2 & 37.6 & 44.0 & 57.8 & 67.8 & 5.9 & 3.3 \\
\hline Average from 55 years & 21.3 & 18.6 & 23.1 & 44.7 & 67.7 & 84.5 & 76.7 & 55.9 & 40.3 & 32.0 & 28.7 & 26.9 \\
\hline
\end{tabular}




\section{RESULTS AND DISCUSSIONS}

Maize production, is influenced by the system tillage, influences induced by it in the culture protection, but also under the influence of climatic factors, in specially temperature and precipitation. Environmental conditions characteristic of the Transylvanian Plain, will result in a favourable microclimate, frequent manifestation of disease especially Fusarium root (caused by the fungus of the genus Fusarium) stem and cob that may diminish the harvest by up to $50 \%$ and pitch (Ustilago maydis) requiring mandatory treatment with the fungicide seed used in the experiment (e.g. Royal Flo 42 S, 3 l/t seed).

Corn is attacked by numerous pests of seedlings from sprays against pests and until after 8 leaf sprays against pests (Agriotes spp., Autographa spp., Ostrinia nubilalis, Phyllotreta Diabrotica virgifera virgifera etc) that's why seed should be treated with insecticide plus fungicide treatments on vegetation. Weeds present frequently in culture, in the area, Echinochloa crus-galli, Setaria spp., monocotyledonous annual; Agropyron repens, monocotyledonous perennial; Xanthuim strumarium, Amaranthus sp., Atriplex, Chenopodium album ap Galeopsis tetrahit, Hibiscus trionum, Polygonum convolvulus, Sonchus oleraceus, Raphanus raphanistrum, dicotyledonous plants, annuals; Convolvulus arvensis, Cirsium arvense,
Lathyrus tuberosus, Lepidium draba, Rubus caesius, Symphitum officinale, a perennial dicotyledonous plants.

At the cultural hygiene corn contributes directly a rotation crops, work the soil (soil preparation for sowing), fertilization, sowing, crop-weed maintenance, disease, pests. Choosing the right hybrid that take full advantage of the potential of soil and climatic factors along with compliance with all technological chain, represents the basic element to produce a healthy and high production. Periodical review of the evolution of climatic factors is fully justified, especially in the current context, when numerous information from literature draws attention to changes on the local level, global warming.

Maize has demonstrated, since the first year of the application of conservative system that needs a piece of soil aeration. That is why it calls each year to a slaughter of the experimental plots where they are planting corn. Slaughter was realised at $30 \mathrm{~cm}$ depth for the maintenance of plant debris from the surface of the soil. This cannot be considered a departure from conservative farming but an adaptation to the conditions of the soil with clay and $46 \%$ with trends of consolidation.

Maize yields recorded in those two years are the cultivation of conventional system with

Tab. 4. The production obtained at maize to the system tillage, ARDS Turda, 2012

\begin{tabular}{ccccc}
\hline $\begin{array}{c}\text { The } \\
\text { variant }\end{array}$ & $\begin{array}{c}\text { The average weight } \\
\text { cobs/plot, kg }\end{array}$ & $\begin{array}{c}\text { The average weight } \\
\text { grains at 5 kg cobs }\end{array}$ & $\begin{array}{c}\text { The average humidity of } \\
\text { the grain harvested }\end{array}$ & $\begin{array}{c}\text { Average yiels } \\
\text { kg/ha, } 15.5 \mathrm{U} \%\end{array}$ \\
\hline $\mathrm{A}_{1} \mathrm{~B}_{1} \mathrm{C}_{1}$ & 17215 & 4206 & 18.0 & 4687 \\
\hline $\mathrm{A}_{1} \mathrm{~B}_{1} \mathrm{C}_{2}$ & 16084 & 4163 & 17.7 & 4348 \\
\hline $\mathrm{A}_{1} \mathrm{~B}_{1} \mathrm{C}_{3}$ & 16669 & 4202 & 18.5 & 4507 \\
\hline $\mathrm{A}_{1} \mathrm{~B}_{1} \mathrm{C}_{4}$ & 15993 & 4263 & 18.5 & 4386 \\
\hline $\mathrm{A}_{1} \mathrm{~B}_{2} \mathrm{C}_{1}$ & 18926 & 4208 & 17.2 & 5203 \\
\hline $\mathrm{A}_{1} \mathrm{~B}_{2} \mathrm{C}_{2}$ & 16709 & 4207 & 18.1 & 4538 \\
\hline $\mathrm{A}_{1} \mathrm{~B}_{2} \mathrm{C}_{3}$ & 15718 & 4161 & 18.2 & 4220 \\
\hline $\mathrm{A}_{1} \mathrm{~B}_{2} \mathrm{C}_{4}$ & 16917 & 4213 & 18.7 & 4570 \\
\hline $\mathrm{A}_{1} \mathrm{~B}_{1} \mathrm{C}_{2}$ & 15000 & 4237 & 18.0 & 4112 \\
\hline $\mathrm{A}_{2} \mathrm{~B}_{1} \mathrm{C}_{2}$ & 14585 & 4247 & 17.7 & 4021 \\
\hline $\mathrm{A}_{2} \mathrm{~B}_{1} \mathrm{C}_{3}$ & 16701 & 4247 & 18.5 & 38363 \\
\hline $\mathrm{A}_{2} \mathrm{~B}_{1} \mathrm{C}_{4}$ & 14116 & 4219 & 18.5 & 4131 \\
\hline $\mathrm{A}_{2} \mathrm{~B}^{2} \mathrm{C}_{1}$ & 14963 & 4225 & 17.2 & 3919 \\
\hline $\mathrm{A}_{2} \mathrm{~B}_{2} \mathrm{C}_{2}$ & 14391 & 4219 & 18.1 & 4116 \\
\hline $\mathrm{A}_{2} \mathrm{~B}_{2} \mathrm{C}_{3}$ & 15150 & 4213 & 18.2 & 4084 \\
\hline $\mathrm{A}_{2} \mathrm{~B}_{2} \mathrm{C}_{4}$ & 15289 & 4165 & 18.7 & \\
\hline
\end{tabular}


plowghing system compared to the minimum work with chisel plowgh, have demonstrated once again that year (climatic conditions of temperature and precipitation) makes the harvest. Thus in the year 2012 (table 4) characterized as a dry year, prolonged drought from June to August have had a negative effect on the crop. In the 3 leafs phenophases, when the root of maize has already recorded a rapid growth and capacity of absorption of nutrients and water, additional fertilization is very important, an addition of nutrients.

However, due to low soil moisture, nitrogen fertilizers applied were decomposed more slowly was absorbed later. In the year 2013 (table 5) precipitation in the months of April-May-June (53.3-79.3-86.2 $\mathrm{mm}$ value) compared to the average over the past 55 years in those months
(44.7-67.7-84.5 $\mathrm{mm}$ value) resulted in higher production compared to the previous year, differences in both systems work. However corn grown in conventional system achieved higher yields from the minimum system with chisel plough in those two years, differences between 352-689 $\mathrm{kg} / \mathrm{ha}$ in the variant with a single fertilization (to sow) and $414-572 \mathrm{~kg} / \mathrm{ha}$ in the version with basic fertilization (the seeding) additional fertilization in 3-5 leaf swprays against pests of maize.

The treatments on vegetation, tilling, fertilizing, taken alone does not ensure significant production increases without insurance statistics (table 6). But this has been found not to waive treatments that ensure the protection of culture. Instead, however, the year in complex with other factors influencing production (table 7). Higher

Tab. 5. The average production obtained at corn according to the system tillage, ARDS Turda, 2013

\begin{tabular}{lcccc}
\hline The variant & $\begin{array}{c}\text { The average weight } \\
\text { cobs/plot, kg }\end{array}$ & $\begin{array}{c}\text { The average weight } \\
\text { grains at 5 kg cobs }\end{array}$ & $\begin{array}{c}\text { The average humidity } \\
\text { of the grain harvested }\end{array}$ & $\begin{array}{c}\text { Average yiels } \\
\text { kg/ha, } 15.5 \text { U \% }\end{array}$ \\
\hline $\mathrm{A}_{1} \mathrm{~B}_{1} \mathrm{C}_{1}$ & 20930 & 4056 & 19.9 & 5365 \\
\hline $\mathrm{A}_{1} \mathrm{~B}_{1} \mathrm{C}_{2}$ & 20520 & 4021 & 19.4 & 5248 \\
\hline $\mathrm{A}_{1} \mathrm{~B}_{1} \mathrm{C}_{3}$ & 20229 & 4069 & 18.7 & 5278 \\
\hline $\mathrm{A}_{1} \mathrm{~B}_{1} \mathrm{C}_{4}$ & 20576 & 4104 & 19.3 & 5377 \\
\hline $\mathrm{A}_{1} \mathrm{~B}_{2} \mathrm{C}_{1}$ & 20164 & 4082 & 18.8 & 5273 \\
\hline $\mathrm{A}_{1} \mathrm{~B}_{2} \mathrm{C}_{2}$ & 19792 & 4017 & 18.7 & 5099 \\
\hline $\mathrm{A}_{1} \mathrm{~B}_{2} \mathrm{C}_{3}$ & 18322 & 4053 & 18.6 & 4773 \\
\hline $\mathrm{A}_{1} \mathrm{~B}_{2} \mathrm{C}_{4}$ & 18899 & 4080 & 19.0 & 4930 \\
\hline $\mathrm{A}_{1} \mathrm{~B}_{1} \mathrm{C}_{2}$ & 18543 & 3023 & 24.3 & 4456 \\
\hline $\mathrm{A}_{2} \mathrm{~B}_{1} \mathrm{C}_{2}$ & 19816 & 3992 & 24.3 & 4726 \\
\hline $\mathrm{A}_{2} \mathrm{~B}_{1} \mathrm{C}_{3}$ & 19498 & 4984 & 23.7 & 4675 \\
\hline $\mathrm{A}_{2} \mathrm{~B}_{1} \mathrm{C}_{4}$ & 19677 & 4001 & 25.1 & 4656 \\
\hline $\mathrm{A}_{2} \mathrm{~B}_{2} \mathrm{C}_{1}$ & 19012 & 4017 & 24.3 & 4562 \\
\hline $\mathrm{A}_{2} \mathrm{~B}_{2} \mathrm{C}_{2}$ & 19994 & 4003 & 24.6 & 4784 \\
\hline $\mathrm{A}_{2} \mathrm{~B}_{2} \mathrm{C}_{3}$ & 19666 & 4045 & 25.2 & 4644 \\
\hline $\mathrm{A}_{2} \mathrm{~B}_{2} \mathrm{C}_{4}$ & 18370 & 24.5 & 4429 \\
\hline
\end{tabular}

Tab. 6. Maize yields recorded in the two systems work, studied, during the period 2012-2013

\begin{tabular}{ccc}
\hline \multirow{2}{*}{ The variant } & \multicolumn{3}{c}{ Yield, kg/ha } \\
\cline { 2 - 3 } & 2012 & 2013 \\
\hline $\mathrm{A}_{1} \mathrm{~B}_{1}$ & 4484 & 5317 \\
\hline $\mathrm{A}_{2} \mathrm{~B}_{1}$ & 4132 & 4628 \\
\hline Differences & 352 & 689 \\
\hline $\mathrm{A}_{1} \mathrm{~B}_{2}$ & 4633 & 5019 \\
\hline $\mathrm{A}_{2} \mathrm{~B}_{2}$ & 4063 & 4605 \\
\hline Differences & 570 & 414 \\
\hline
\end{tabular}


Tab. 7. Influence of technological factors on the production of maize, ARDS Turda, 2012-2013

\begin{tabular}{|c|c|c|c|c|c|c|c|c|c|}
\hline \multirow{2}{*}{\multicolumn{2}{|c|}{$\begin{array}{c}\text { The factor } \\
\text { Value }\end{array}$}} & \multicolumn{2}{|c|}{ System of soil work } & \multicolumn{2}{|c|}{ Treatments } & \multicolumn{2}{|c|}{ Agrofond } & \multicolumn{2}{|c|}{ Year } \\
\hline & & $\mathrm{SC}$ & $4131^{\mathrm{Mt}}$ & $\mathrm{T}^{\mathrm{Mt}}$ & 4117 & $\mathrm{~A}_{1}^{\mathrm{Mt}}$ & 4127 & $\mathrm{D}_{1}^{\mathrm{Mt}}$ & 4212 \\
\hline & & MT & 4116 & $\mathrm{~T} 1$ & 4132 & $\mathrm{~A}_{2}$ & 4121 & $\mathrm{D}_{2}$ & 4035 \\
\hline & & & & $\mathrm{T} 2$ & 4111 & & & & \\
\hline & & & & $\mathrm{T} 4$ & 4136 & & & & \\
\hline \multirow{3}{*}{\multicolumn{2}{|c|}{ Differences }} & MT & -16 & $\mathrm{~T} 1$ & 15 & $\mathrm{~A}_{2}$ & -7 & $\mathrm{D}_{2}$ & -177 \\
\hline & & & & $\mathrm{T} 2$ & -6 & & & & \\
\hline & & & & $\mathrm{T} 4$ & 20 & & & & \\
\hline \multirow{3}{*}{\multicolumn{2}{|c|}{ Semnification }} & MT & - & T1 & - & $\mathrm{A}_{2}$ & - & $\mathrm{D}_{2}$ & 000 \\
\hline & & & & $\mathrm{T} 2$ & - & & & & \\
\hline & & & & $\mathrm{T} 4$ & - & & & & \\
\hline \multirow{3}{*}{ DL } & $5 \%$ & \multicolumn{2}{|r|}{46} & \multicolumn{2}{|c|}{27} & \multicolumn{2}{|c|}{15} & \multicolumn{2}{|c|}{22} \\
\hline & $1 \%$ & & 106 & \multicolumn{2}{|c|}{38} & \multicolumn{2}{|c|}{20} & \multicolumn{2}{|c|}{30} \\
\hline & $0.1 \%$ & \multicolumn{2}{|r|}{338} & \multicolumn{2}{|c|}{54} & \multicolumn{2}{|c|}{28} & \multicolumn{2}{|c|}{40} \\
\hline
\end{tabular}

Legend: A-soil work system: A1-classic with plowghing, minimum tillage option A2-chisel plowgh; B-agrofond: B1 fertilization with NPK (20: 20: 0) $200 \mathrm{~kg} \backslash / \mathrm{ha}$ s.a. together with sowing, fertilization with NPK B2 (20:20: 0) $200 \mathrm{~kg} \backslash / \mathrm{ha}$ sowing simultaneously with fertilization s.a. additional N40 in sprays against pests 3-5 leaves of corn plants. C-treatments: C1- IF +IS: (Polyfeed + Calypso) in sprays against pests 3-5 leaves of maize plus one therapy with IF +IS (Polyfeed + Calypso) sprays against pests in 7-9 leaves; C2- IS (Calypso) in 3-5 leafs sprays against pests + IF the sprays against pests and 7-9 leafs; C3- IF+IS (Polyfeed+Calypso) in 3-5 leaves sprays against pests and IF (Polyfeed) in sprays against pests and 7-9 leaves; C4- IF (Polyfeed) in 3-5 leaves sprays against pests.

Tab. 8. The influence of interaction beetwen tillage system $x$ on maize yield capacity, ARDS Turda, 2012 $-2013$

\begin{tabular}{ccccccc}
\hline Year & Tillage system & Fertilization & $\begin{array}{c}\text { Yield, } \mathrm{kg} / \\
\mathrm{ha}\end{array}$ & $\begin{array}{c}\text { Yield } \\
\%\end{array}$ & $\begin{array}{c}\text { Differences, } \\
\pm \mathrm{kg} / \mathrm{ha}\end{array}$ & Semnification \\
\hline 2012 & Classic & $\mathrm{B}_{1}$ (one fertlilizing) & 4209 & 100.0 & 0 & Mt. \\
\hline 2013 & Classic & $\mathrm{B}_{1}$ (one fertilizing) & 4063 & 96.5 & -146 & 000 \\
\hline 2012 & Classic & $\mathrm{B}_{2}$ (two fertilizing) & 4197 & 100.0 & 0 & Mt. \\
\hline 2013 & Classic & $\mathrm{B}_{2}$ (two fertilizing) & 4058 & 96.7 & -139 & 000 \\
\hline 2012 & Minimum tillage & $\mathrm{B}_{1}$ (one fertilizing) & 4237 & 100.0 & 0 & Mt. \\
\hline 2013 & Minimum tillage & $\mathrm{B}_{1}$ (one fertilizing) & 4000 & 94.4 & -237 & 000 \\
\hline 2012 & Minimum tillage & $\mathrm{B}_{2}$ (two fertilizing) & 4206 & 100.0 & 0 & Mt. \\
\hline 2013 & Minimum tillage & $\mathrm{B}_{2}$ (two fertilizing) & 4021 & 95.6 & -185 & 000 \\
\hline
\end{tabular}

DL $5 \%=45 \mathrm{~kg} / \mathrm{ha} ;$ DL $1 \%=60 \mathrm{~kg} / \mathrm{ha}$; DL $0.1 \%=80 \mathrm{~kg} / \mathrm{ha}$.

production values are obtained in the richer in precipitation that provide fertilizer applied in solubilizing the early stages of vegetation, therefore production increases were relatively small in both 2012 and 2013 (table 8), the differences being between $45-80 \mathrm{~kg} / \mathrm{ha}$.

\section{CONCLUSION}

Corn production in 2012 is greater in the classic work of the soil (regarded as) with 352 $\mathrm{kg} / \mathrm{ha}$ in the variant with a single fertilization (simultaneously with the sowing) and $570 \mathrm{~kg} /$ ha in two variant derived from the output in the system with the minimum of ground works (the chisel plowgh).

The influence of the years are very strong, for the production of corn, has led to the overcoming of the classical minimum system with differences being recorded productions of $689 \mathrm{~kg} / \mathrm{ha}$ (variant 
with a fertilization) and $414 \mathrm{~kg} / \mathrm{ha}$ (two derived). In the two years taken into study, due to prolonged drought, climatic factors correlated with high temperatures of hybrid corn could not achieve production parameters in normal years of climatic point of view, are superior to the last few years.

The research results reveal that corn is snobbish towards the work of the soil, from soil type, climatic conditions, production results confirming this.

The production results obtained in the two systems work the soil have close values, but it should be borne in mind that by applying minimum tillage systems on soil chasing the fight against soil erosion and retention of water in the soil.

After a number of years (theoretically 10 years), when conservative system settled, we will be able to verify the theory of restoration of natural fertility of soil, humus content and increase biodiversity, recovery of microbial life of the soil.

Acknowledgments: This paper was published under the frame of European Social Fund, Human Resources Development Operational Programme 2007-2013, projectno. POSDRU/159/1.5/S/132765.

\section{REFERENCES}

1. Brown, L., R., 1988, Probleme globale ale omenirii, pag:158, Ed. Tehnică, Oradea.

2. Bucur, D., G. Jitareanu, C. Ailincai, 2011, Effects of longterm soil and crop management on the yield and on the fertility of eroded soil. Journal of Food, Agriculture \& Environment Vol.9 (2): 207 - 209.

3. Chețan, F., Deac, V., Şimon, A., Chețan, C., 2013, The influence of Tillage System on production and quality of soybean yield at Agricultural Research-Development Station Turda.The 7th International Symposium,, Soil Minimum Tillage Systems" vol.6 .No.14: 362, Ed.Bioflux, Cluj - Napoca.

4. Chețan, F., Chețan, C., Deac, V., Şimon, A., Ignea, M., 2013, The cultivation of soybean in Agricultural Conservative System and its role in protection of the environment The 12th International Symposium Prospects for the $3^{\text {rd }}$ Millennium agriculture.

5. Fabrizzi, K.P., F.O. Garcia, J.L. Costa, L.I. Picone, 2005, Soil water dynamics, physical properties and corn and wheat responses to minimum and no-tillage systems in the southern Pampas of Argentina. Soil \& Tillage Research 81: $57-69$.

6. Grecu, C., Ignea, M., Copândean, A., 2011, Evoluția regimului termic şi pluviometric la Turda în perioada 1957 - 2010. Agricultura Transilvană, Buletin informativ, martie, nr. 14. Ed.Ela Design SRL, Turda.

7. Guş, P., S. Cernea, T. Rusu, I. Bogdan, 2004, Sisteme de semănat, fertilizat si întreţinere a culturilor. Editura Risoprint, Cluj-Napoca, p. 52.
8. Gus, P., Rusu, T., 2011. Unconventional soil tillage systems, agrotehnical and economical alternative for durable agriculture. The $6^{\text {th }}$ International Symposium, Soil Minimum Tillage Systems", p: 11-21. Ed. Risoprint, ClujNapoca.

9. Haș, V., Haș, I., Antohola, I., Copândean, A., Nagy, E., 2010, Variabilitatea capacității de producție şi calității boabelor la hibrizii de porumb din diferite grupe de maturitate FAO. Anale INDCA Fundulea, vol. XXVIII, pag: 38 - 47.

10. Ivaș Adina, Felicia Mureșanu, Voichița Haș, 2013, The Evolution of the most important pest species of maize crops in different soil tillage systems at ARDS Turda. In The $7^{\text {th }}$ International Symposium „Soil Minimum Tillage Systems" Cluj-Napoca, 2 - 3 May 2013, p. 144 - 150.

11. Malschi, D., Ivas, A. D., Ignea, M., Chetan, F., Chețan C. "Adequate Integrated Control of Wheat Pest in No - tillage Conservative System". The $7^{\text {th }}$ International Symposium „Soil Minimum Tillage Systems” Cluj-Napoca, 2 - 3 May 2013.

12. Marin, D. I., T. Rusu, M. Mihalache, L. Ilie, C. Bolohan, 2012, Research on the influence of soil tillage system upon pea crop and some properties of reddish preluvosoil in the Moara Domneasca area. Annals of the University of Craiova - Agriculture, Montanology, Cadastre Series, Vol. 42, No 2: 487 - 490.

13. Moraru, P. I., T. Rusu, M. L. Sopterean, 2010, Soil Tillage Conservaton and its Effect on Erosion Control, Water Management and Carbon Sequestration. In ProEnvironment/ProMediu no. 3.

14. Moraru, P. I., T. Rusu, 2010, Soil tillage conservation and its effect on soil organic matter, water management and carbon sequestration. Journal of Food, Agriculture \& Environment, 8 (3 - 4), 309 - 312.

15. Muntean, L., S., Cernea, S., Morar, G., Duda, M., Vârban, D., Muntean, S., 2008, Fitotehnie, Editura Academic Pres, Cluj - Napoca.

16. Rusu, T., P. I. Moraru, C. L. Coste, H. Cacovean, F. Chețan, C. Chețan, 2014, Impact of climate change on climatic indicators in Transylvanian Plain, Romania. Journal of Food, Agriculture \& Environment Vol. 12 (1): 469 - 473.

17. Rusu, T., Guș, P., 2007, Soil Compaction, Processes and consequences, pag: 24 - 24, Ed. Risoprint, Cluj - Napoca.

18. Rusu, T., Imre, A., Bodiș, A., 2005, Metode și tehnici de producție în agricultura ecologică, Ed. Risoprint, Cluj Napoca.

19. Rusu, T., 2005, Agrotehnica, pag; 221- 222; 414. Ed. Risoprint Cluj-Napoca.

20. Scurtu I.,2001, Economia și tehnologia culturilor agricole, pag: 231-232-236. Ed. Independența economică, Pitești.

21. Șimon A, Chețan C, Chețan F, Deac V, Ignea M, The 12th International Symposium " Prospects for the 3rd millenium agriculture"," The influence of different densities on production of maize hybrids cultivated in the conservative agricultural system", Cluj-Napoca, 26 - 28 septembrie 2013.

22. FAOSTAT | (C) FAO Statistics Division 2014 | 27 May 2014. 